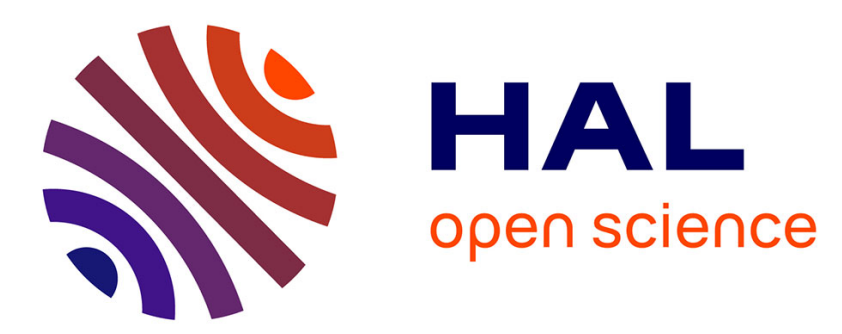

\title{
Unexpected spatial stability of water chemistry in headwater stream networks
}

Benjamin Abbott, Gérard Gruau, Jay P. Zarnetske, Florentina Moatar, Lou

Barbe, Zahra Thomas, Ophélie Fovet, Tamara Kolbe, Sen Gu, Anne-Catherine Pierson-Wickmann, et al.

\section{To cite this version:}

Benjamin Abbott, Gérard Gruau, Jay P. Zarnetske, Florentina Moatar, Lou Barbe, et al.. Unexpected spatial stability of water chemistry in headwater stream networks. Ecology Letters, 2018, 21 (2), pp.296-308. 10.1111/ele.12897 . insu-01674523

\section{HAL Id: insu-01674523 \\ https://hal-insu.archives-ouvertes.fr/insu-01674523}

Submitted on 12 Apr 2018

HAL is a multi-disciplinary open access archive for the deposit and dissemination of scientific research documents, whether they are published or not. The documents may come from teaching and research institutions in France or abroad, or from public or private research centers.
L'archive ouverte pluridisciplinaire HAL, est destinée au dépôt et à la diffusion de documents scientifiques de niveau recherche, publiés ou non, émanant des établissements d'enseignement et de recherche français ou étrangers, des laboratoires publics ou privés. 
2 Running title: Structure of water quality in stream networks

3 Authors: Benjamin W. Abbott ${ }^{1,2,3}$, Gérard Gruau ${ }^{4}$, Jay P. Zarnetske ${ }^{2}$, Florentina Moatar ${ }^{5}$, Lou Barbe ${ }^{3}$, Zahra

4 Thomas $^{6}$, Ophélie Fovet ${ }^{6}$, Tamara Kolbe ${ }^{4}$, Sen $\mathrm{Gu}^{4}$, Anne-Catherine Pierson-Wickmann ${ }^{4}$, Philippe Davy ${ }^{4}$, Gilles

$5 \quad$ Pinay $^{3,7}$

6 Affiliations: ${ }^{1}$ Brigham Young University, Department of Plant and Wildlife Sciences, Provo, USA; ${ }^{2}$ Michigan

7 State University, Department of Earth and Environmental Sciences, East Lansing, USA; ${ }^{3}$ ECOBIO, OSUR,

8 CNRS, Université de Rennes 1, 35045 Rennes, France;; ${ }^{4}$ OSUR, CNRS, UMR 6118, Géosciences Rennes,

9 Université de Rennes 1, 35045 Rennes, France; ${ }^{5}$ University François-Rabelais Tours, EA 6293 Géo-

Hydrosystèmes Continentaux, Parc de Grandmont, 37200 Tours, France; ${ }^{6}$ UMR SAS, AGROCAMPUS OUEST,

11 INRA, 35000 Rennes, France; ${ }^{7}$ MALY, RIVERLY irstea, Lyon-Villeurbanne, France

12 Author emails: benabbott@byu.edu, gerard.gruau@univ-rennes1.fr, jpz@msu.edu, florentina.moatar@univtours.fr, lou.barbe@univ-rennes1.fr, zthomas@agrocampus-ouest.fr, ophelie.fovet@inra.fr, tamara.kolbe@univrennes1.fr, sen-gu2013@hotmail.com, anne-catherine.pierson-wickmann@univ-rennes1.fr, philippe.davy@univrennes1.fr, gilles.pinay@univ-rennes1.fr

16 Statement of authorship: The conceptual framework for this paper emerged from discussions among all authors. Statistical analysis and writing were led by Abbott with support from Pinay, Gruau, Zarnetske, and

18 Moatar, and input from all authors. Gruau, Abbott, Gu, and Kolbe led field work and sample processing.

Data accessibility statement: All data are attached as supplementary information to this article.

Key words: stream network, synoptic sampling, representative elementary area, critical source area, nutrients, network analysis

Number of words in abstract: 143

Number of cited references: 98

\section{Number of tables \& figures: 6}




\section{Abstract}

29 Understanding how water and solutes enter and propagate through freshwater landscapes in

30 the Anthropocene is critical to protecting and restoring aquatic ecosystems and ensuring

31 human water security. However, hydrochemical variability is believed to increase moving

32 upstream, hindering modeling and management of headwaters where most carbon and

33 nutrients enter stream networks. We developed an analytical framework informed by

34 landscape ecology and catchment hydrology to quantify spatiotemporal variability across

35 scales, which we tested in 56 headwater catchments, sampled periodically over 12 years in

36 western France. Unexpectedly, temporal variability of dissolved carbon, nutrients, and major

37 ions was preserved moving downstream and spatial patterns of water chemistry were stable

38 on annual to decadal timescales, partly due to synchronous variation of solute concentrations.

39 These findings suggest that while concentration and flux cannot be extrapolated among

40 subcatchments, periodic sampling of headwaters provides valuable information about solute

41 sources and subcatchment resilience to disturbance.

42 


\section{Introduction}

How spatial and temporal variability change with scale is one of the fundamental problems of both ecology (Fisher et al. 1982; Horne \& Schneider 1995; Altermatt 2013) and catchment hydrology (Blöschl et al. 1995; Shaman et al. 2004; McGuire et al. 2014). Because most ecological patterns change with spatiotemporal extent and grain of observation (Turner et al. 1989; Chapin et al. 1995; Kirchner \& Neal 2013), an understanding of variance structure is necessary to scale predictions or implement effective interventions in dynamic landscapes (Haygarth et al. 2005; Lowe et al. 2006; Temnerud et al. 2010). For any ecosystem, variability in a biogeochemical stock or flux depends on on-site conditions and processes (e.g. temperature, redox state, biological activity, weathering) and lateral subsidies or debits from connected ecosystems (Chapin et al. 2006). Lateral fluxes are particularly influential in aquatic ecosystems such as stream networks, where delivery of carbon and nutrients from upstream and upslope environments is often orders of magnitude greater than production or removal at any given point in the stream (Lefebvre et al. 2007; Brookshire et al. 2009). Agriculture and urbanization have fundamentally altered lateral fluxes of carbon and nutrients, causing eutrophication, toxic cyanobacteria blooms, and expansive hypoxic dead zones that erode the capacity of ecosystems to feed and water human societies (Gruber \&

Galloway 2008; Vörösmarty et al. 2010; Sutton \& UNEP 2013; Withers et al. 2014). Over the past 50 years, global fertilizer application has increased 5-fold (Foley et al. 2011), and anthropogenic pressures on aquatic ecosystems are expected to intensify due to population growth and increasing meat consumption through the middle of the century (Seitzinger et al. 2010).

Despite substantial investment to reduce carbon and nutrient pollution at local, national, and international levels, results remain mixed (Jarvie et al. 2013; Dupas et al. 2016; 
Jenny et al. 2016), partly because of difficulty monitoring and predicting water quality in complex freshwater landscapes (Isaak et al. 2014; Abbott et al. 2016; Meter et al. 2016). Most regulatory frameworks, such as the U.S. Clean Water Act, the European Water Framework Directive, and the Chinese Water Law impose limits on annual loads or mean concentrations in medium to large rivers (Andreen 2004; Hering et al. 2010; Liu \& Yang 2012). This is an appealing strategy because larger rivers integrate many small catchments, and from an estuarine or oceanic perspective, total nutrient load is the main metric of concern (Howarth 2008; Reed \& Harrison 2016). However, there is growing evidence that to reduce these downstream nutrient fluxes, we need to understand sources and sinks in headwater catchments, where the vast majority of water and solutes enter aquatic ecosystems (Burt \& Pinay 2005; Alexander et al. 2007; Bishop et al. 2008; Brookshire et al. 2009; McDonnell \& Beven 2014).

It is generally held that the amplitude and frequency of chemical variation in stream networks decrease moving downstream (Burt \& Pinay 2005; Lefebvre et al. 2007; Creed et al. 2015). For example, in catchments larger than $100 \mathrm{~km}^{2}$, riverine nutrient loads are deterministically associated with percentage of agricultural cover and associated nutrient inputs (Omernik et al. 1981; Jordan et al. 1997; Howarth 2008), but nutrient loads vary widely despite similar land cover in drainage basins smaller than $20 \mathrm{~km}^{2}$ (Burt \& Pinay 2005; Lefebvre et al. 2007; Brookshire et al. 2009; Schilling et al. 2013). This breakdown of the relationship between land cover and nutrient load represents an important ecological unknown because $90 \%$ of global stream length occurs in catchments smaller than $15 \mathrm{~km}^{2}$ (Burt \& Pinay 2005; Bishop et al. 2008; Downing 2012). However, quantifying and improving water quality in headwater streams is easier said than done. New sensors of water chemistry produce highfrequency data (Kirchner et al. 2004; Dupas et al. 2016; Ruhala \& Zarnetske 2017), but they are too expensive to equip headwater catchments, which are thousands of times more 
abundant than the larger rivers where most monitoring currently occurs. This headwater conundrum is particularly problematic for developing nations where the largest increases in nutrient pollution are occurring (Seitzinger et al. 2010), and where water quality problems most directly impact human health (Gundry et al. 2004).

Occasional, spatially extensive sampling of headwater streams has long been used to complement high-frequency monitoring of downstream reaches (Kaufmann et al. 1991; Wolock et al. 1997; Temnerud \& Bishop 2005). Such synoptic sampling is often interpreted to identify landscape parameters and ecosystem processes correlated with water chemistry, but its utility in predicting longer-term water quality is questionable, given the high temporal variability typical of small aquatic ecosystems (Kirchner \& Neal 2013). In this context, we developed a new approach for analyzing spatiotemporal variance in stream networks. Specifically, building on theory from landscape ecology (Turner et al. 1989; Dent \& Grimm 1999; Hammond \& Kolasa 2014) and catchment hydrology (Blöschl et al. 1995; Rinaldo et al. 1998; McGuire et al. 2014), we quantified the synchrony of hydrochemical changes, the stability of spatial patterns, and the spatial scales of water chemistry drivers. We tested this framework with a previously unpublished dataset from 56 catchments sampled periodically over 12 years in western France. We found that while spatial variance of water chemistry increased moving upstream, temporal variance was not systematically higher in the headwaters, partially because solute concentrations (e.g. carbon and nutrients) varied synchronously among sites. These dynamics created spatial patterns of water chemistry that were relatively stable on seasonal to decadal timescales, suggesting that the spatiotemporal variability of headwaters may not be as intractable as previously believed. Testing the generality of these patterns in different climatic and socioecological conditions could provide a pathway toward understanding terrestrial-aquatic connectivity and improving water quality throughout the river network. 


\section{Approach and methods}

118

120

121

122

123

124

125

126

\section{Spatial variance thresholds and subcatchment leverage}

While pollutant sources have long been categorized dichotomously as point or nonpoint (Carpenter et al. 1998), landscape patches contributing or retaining solutes or particulates occur on a size continuum that can change on event, seasonal, and interannual timescales (Basu et al. 2010; Liu et al. 2016). Assuming that spatial variability in water chemistry in a stream network depends primarily on the extent and connectivity of upstream sources, we hypothesized that the size of source and sink patches could be assessed by the spatial scale of the collapse (i.e. reduction) in spatial variance (Fig. 1). For a given parameter, this spatial variance threshold is expected to occur where subcatchment size matches the size of patches controlling solute production or removal (Fig. 1b), with downstream reaches less likely to have extreme concentrations because they integrate multiple source and sink patches. The spatial variability of concentration depends on the strength and connectivity of both source and sink patches superimposed on the structure of the stream network (Fig. 1). This framework is analogous to the representative elementary area concept (Blöschl et al. 1995; Hoef et al. 2006; Zimmer et al. 2013), though we do not assume that variance thresholds remain the same through time or across solutes.

On an applied level, knowing the patch size and location of solute sources and sinks allows identification of subcatchments exerting a disproportionate influence on flux at the catchment outflow (Fig. 1c). Analogous to the concept of leverage in statistical regression, where a value's relative influence on model behavior depends on its position in factor space, the leverage of a subcatchment on outlet chemistry can be defined in terms of concentration difference from the catchment outlet, subcatchment size, and specific discharge:

$$
\text { Subcatchment leverage }=\left(C_{S}-C_{O}\right) \times A_{S} / A_{O} \times Q_{S} / Q_{O}
$$


141 where $\mathrm{C}$ is concentration, $\mathrm{A}$ is area, $\mathrm{Q}$ is specific discharge, $\mathrm{S}$ is subcatchment, and $\mathrm{O}$ is

142 outflow. Subcatchment leverage has units of concentration, or percentage if normalized to

143 outlet concentration, and can be interpreted as the contribution of the subcatchment to

144 catchment-level mass flux. Alternatively stated, subcatchment leverage is the spatially

145 distributed mass balance for each element. If specific discharge is similar between

146 subcatchments, as is sometimes the case at the medium-catchment scale (Asano et al. 2009;

147 Lyon et al. 2012; Karlsen et al. 2016), leverage can be estimated with only concentration and

148 subcatchment area, which are easily measured even in remote or impoverished areas. Spatial

149 variance thresholds tend to occur at the same spatial scales as the subcatchments with greatest

150 leverage, where a large proportion of the subcatchment area is within a single source or sink

151 patch (Fig. 1c).

152 Subcatchment synchrony and spatial stability

153 The usefulness of a synoptic assessment of variance thresholds and subcatchment

154 leverage depends directly on the temporal persistence of the observed spatial patterns.

155 Streams experience temporal variability in chemistry due to hydrologic pulses and

156 fluctuations in biogeochemical activity (Rinaldo et al. 1998; Erlandsson et al. 2008; Raymond

157 et al. 2016). As pulses move through stream networks, their downstream attenuation or

158 preservation depends on the synchrony of pulse generation in subcatchments (Fig. 2a). If the

159 chemistry of upstream subcatchments changes asynchronously, destructive interference

160 reduces downstream temporal variance, but if change is synchronous, downstream temporal

161 variance is preserved (Fig. 2b). Synchrony among subcatchments can be quantified by

162 temporal covariance in water chemistry:

163

Subcatchment synchrony $=\frac{\sum_{i=1}^{n}\left(x_{i}-\bar{x}\right)\left(y_{i}-\bar{y}\right)}{n-1}$ 
164 where $\mathrm{x}$ and $\mathrm{y}$ are the concentrations in the two subcatchments and $\mathrm{n}$ is number of repeat 165 samplings.

166

167

168

169

Even when concentrations vary synchronously among subcatchments, the relative spatial structure in the stream network can change if amplitudes are different (Fig. 2a). Spatial stability of water chemistry patterns can be directly calculated with the rank correlation $\left(\mathrm{r}_{\mathrm{s}}\right)$ between instantaneous and long-term subcatchment concentrations:

$$
\text { Spatial stability }=\frac{\text { covariance }\left(\mathrm{RC}_{t}, \mathrm{RC}_{\bar{t}}\right)}{\sigma_{\mathrm{RC}} \sigma_{\mathrm{RC}}}
$$

where spatial stability is the correlation coefficient between the rank concentrations of subcatchments at the time of synoptic sampling $\left(R C_{t}\right)$ and the rank of the long-term flowweighted concentrations or loads $\left(R C_{\bar{t}}\right)$, and $\sigma$ is the standard deviation. Subcatchment synchrony and spatial stability are complementary because synchrony quantifies similarity in response to hydrologic and biological changes, revealing prevalence of source, transport, and processing controls (Moatar et al. 2017), and spatial stability quantifies the temporal representativeness of an instantaneous sampling.

From an applied perspective, spatial stability in subcatchment water chemistry determines the sampling frequency necessarily to identify high-leverage subcatchments (Figs. 2a and 1c) and evaluate predicted critical source areas (White et al. 2009; Heathwaite 2010; Liu et al. 2016), while subcatchment synchrony determines the representativeness of highfrequency monitoring stations. In a synchronous catchment where pulses of pollutants are propagated in chorus (Fig. 2b), a single station anywhere in the network may capture the amplitude of water quality fluctuations. However, in an asynchronous catchment, destructive interference among subcatchments means downstream monitoring stations will underestimate extreme conditions in contributing subcatchments (Fig. 2b). Accurate quantification of 
temporal variability is particularly important for aquatic organisms, because minimum and maximum concentrations or conditions (e.g. oxygen and temperature) are often more important to survival than mean values, and where shifts in extremes can indicate imminent state changes (Davis et al. 2010). Ultimately, these two indices are interrelated, because in more synchronous catchments the spatial stability is more resilient to temporal variability (Fig. 2c).

\section{Site characteristics and sampling design}

We quantified spatial variance thresholds, subcatchment leverage, subcatchment synchrony, and spatial stability in two sets of nested catchments in north-western France (Fig. S1). The Rance and Couesnon catchments are approximately $360 \mathrm{~km}^{2}$ and have over $80 \%$ agricultural land use, primarily pastureland for dairy cows, corn, and wheat (Table S1). Nutrient concentrations in the area are very high, frequently triggering estuarine algal blooms (Gascuel-Odoux et al. 2010; Perrot et al. 2014). The climate is oceanic with average monthly temperature ranging from $18^{\circ} \mathrm{C}$ in July to $5^{\circ} \mathrm{C}$ in December, and mean annual precipitation averaging 970 mm, a third of which occurs from October to December (Thomas et al. 2016).

Starting in November 2004, repeat synoptic sampling occurred in 26 subcatchments of the Couesnon with an initial goal of identifying land use parameters driving differences in DOC and $\mathrm{NO}_{3}{ }^{-}$concentrations. Detailed land use was determined for the entirety of each subcatchment and for the area of potential wetlands closest to the stream network (Medde et al. 2014). The subcatchments were sampled 13 times (approximately every two weeks), but when no clear correlations emerged with catchment characteristics (Table S2), sampling was abandoned in 2005. After identifying 30 comparable locations in the Rance catchment, 50 km to the west, sampling resumed in both catchments from May 2006 to January 2007. Sampling spanned over $90 \%$ of the observed range of daily discharge for the Couesnon and over $70 \%$ 
211 for the Rance. In November 2015 and March 2016, we resampled 21 of the original 56

212 subcatchments during the low- and high-flow periods, respectively. Because the outlet of the

213 Rance is intermittently inundated by a small reservoir, we calculated outlet solute

214 concentrations assuming conservative mixing of the three tributaries immediately upstream of

215 the confluence with the reservoir. Calculated values agreed well with measured values for

216 dates when the outlet was not inundated.

217 Samples were filtered in the field with pre-rinsed $0.2 \mu \mathrm{m}$ cellulose acetate filters 218 (Millipore Millex-GV), and analyzed within a week. Quantified analytes had a wide range of 219 reactivities and sources, and included many common water quality parameters. Anions $\left(\mathrm{NO}_{3}{ }^{-}\right.$, $220 \mathrm{NO}_{2}^{-}, \mathrm{SO}_{4}{ }^{2-}, \mathrm{Cl}^{-}, \mathrm{F}^{-}, \mathrm{PO}_{4}{ }^{3-}$, and $\mathrm{Br}^{-}$) were quantified by ion chromatography (Dionex ${ }^{\mathrm{TM}} \mathrm{DX}$ 221 100; accuracy $\pm 2.5 \%$ ) and dissolved organic and inorganic carbon (DOC and DIC) were 222 quantified with a total carbon analyzer after coming to equilibrium with the atmosphere 223 (Shimadzu TOC 5050; accuracy \pm 5\%). Specific ultra-violet absorbance at $254 \mathrm{~nm}$ 224 (SUVA 254$)$, an indicator of DOC aromaticity and source (Weishaar et al. 2003), was 225 calculated from absorption (UVIKON XS, Bio-Tek). For concentrations below the detection 226 limit, we assigned values of $\frac{1}{2}$ the limit of quantification, which affected less than $5 \%$ of all 227 measurements except $\mathrm{PO}_{4}{ }^{3-}, \mathrm{NO}_{2}{ }^{-}$, and $\mathrm{Br}^{-}$, which had between 25 and $72 \%$ of sites below 228 detection depending on the catchment and sampling. Despite these detection issues, which are 229 common for these parameters, we retained them in the analysis because of their ecohydrologic 230 relevance.

Statistical determination of spatial and temporal variance

We determined spatial variance thresholds among subcatchments using the pruned 233 exact linear time (PELT) method (Killick et al. 2012), which compares differences among 234 sequential data points (in this case ordered by subcatchment size) to partition the series into 
clusters with statistically distinct variances (Jackson et al. 2005). PELT is computationally frugal and robust to unevenly spaced points (Jackson et al. 2005; Killick et al. 2012). We determined variance thresholds for each watershed independently using flow-weighted concentrations over the whole sampling period, and after binning the data into four groups separated by hydrologic quartiles to test how water discharge affected spatial variance (Table S2), using the “changepoint” package of R version 3.3.0 (R Core Team 2016). Following equations 1-3, we calculated subcatchment leverage, synchrony, and spatial stability with scaled data (subtracted catchment mean and divided by the standard deviation), which did not affect the statistical results, but facilitated comparison between parameters with different magnitudes. For subcatchment synchrony, we averaged the pairwise covariance between all subcatchments for each catchment and parameter. The resulting scaled covariance represents the joint variability across all subcatchments and sampling dates (i.e. the proportion of subcatchments and time steps where concentration changed in the same direction for a given parameter).

\section{Results}

\section{Persistent thresholds of spatial variance and stable subcatchment structure}

While subcatchments had diverse land use and land cover (Table S1), relationships between catchment characteristics and flow-weighted concentrations were typically weak (non-significant or low correlations), and differed by catchment (Table S2). Catchment characteristics in potential wetlands near the stream network were not systematically better at predicting water chemistry than whole-catchment values (Table S2). Spatial variance in concentration decreased with increasing subcatchment size for all parameters, with concentrations trending towards the overall catchment mean, suggesting conservative propagation of headwater signals with limited in-stream modification (Figs. 3A, S2). Spatial 
variance thresholds occurred between 18 and $68 \mathrm{~km}^{2}$ for most parameters, except for DIC in both catchments, and $\mathrm{Cl}^{-}$and $\mathrm{F}^{-}$in the Rance, which had thresholds from 113 to $216 \mathrm{~km}^{2}$ (Figs. 3A, S2A). Variance thresholds were stable across flow conditions for 72 of the 80 parameter by flow quarter combinations (Table S3), suggesting that patch locations and stream network topology determined spatial patterns, rather than changes in hydrology and biogeochemical processing. The relative scale of variance thresholds for different parameters among the two catchments generally followed the same patterns (e.g. larger for DIC, smaller for $\mathrm{PO}_{4}{ }^{3-}$ ). Subcatchment leverage followed the expected pattern (Fig. 1c), with highest leverage at spatial scales just larger than variance thresholds (Fig. S3). Most parameters showed moderate to low leverage, with no single subcatchment accounting for more than $25 \%$ of outflow concentration. However, several subcatchments had extremely high leverage for $\mathrm{PO}_{4}{ }^{3-}$ and $\mathrm{NO}_{2}{ }^{-}(>1000 \%)$, indicating substantial retention or removal of these solutes before reaching the catchment outlet (Fig. S3).

Despite large changes in discharge and concentration (Figs. S4-S6), subcatchment water chemistry showed strong spatial stability for most parameters, meaning the relative rank of subcatchment concentrations changed little across flow conditions (Figs. 4, S7). Spatial stability of water quality among subcatchments was particularly strong for DOC, DIC, $\mathrm{NO}_{3}{ }^{-}$, and several anions (Fig. 5). The parameters with consistently low or variable spatial stability $\left(\mathrm{PO}_{4}{ }^{3-}, \mathrm{NO}_{2}^{-}\right.$, and $\left.\mathrm{Br}^{-}\right)$had a large number of samples at or below the detection limit, artificially decreasing estimates of spatial stability. During the first storm after the summer low-flow period in 2005, spatial stability dropped substantially for most parameters, indicating a spatial reorganization of water quality in the Couesnon catchment (Fig. 4). Subcatchment synchrony (mean covariance among subcatchments), varied from less than 0.25 for some anions to 0.81 for DOC in the Couesnon (Fig. 5B), depending on the 
consistency of concentration-discharge responses among subcatchments (Fig. S4). SUVA 254

284 was substantially less synchronous than DOC (Figs. 4-5), suggesting diversity in DOC

285 sources despite synchronous fluctuations in bulk DOC concentration. Among parameters, spatial stability and synchrony were unrelated to temporal variance (Fig. 5), demonstrating that the overall magnitude of temporal variance did not determine spatial or temporal representativeness. Contrary to our hypotheses (Fig. 2), synchrony and spatial stability were unrelated (Fig. 5C), demonstrating that large differences in concentration among

290 subcatchments can create spatial stability independent of synchrony.

Clearer temporal signals at smaller scales and decadal stability in structure 3B, S2B). Instead, temporal variance followed the same pattern observed for spatial variance of subcatchments (Fig. 3a), with greater diversity left of the spatial variance threshold and a convergence towards the catchment mean at the outlet. Subcatchments smaller than the spatial variance threshold showed greater range in variances, but they were equally likely to be more or less dynamic than the catchment outlets. Catchment outlets had temporal variances near the overall catchment mean for most parameters (Figs. 3B, S2B), suggesting variance damping (mixing of strong and weak signals) rather than destructive interference of opposing signals.

300 However, $\mathrm{NO}_{3}{ }^{-}, \mathrm{SO}_{4}{ }^{2-}$, and $\mathrm{Br}^{-}$showed somewhat lower temporal variance at the catchment 301 outlets, attributable to inconsistent or weak concentration-discharge responses among subcatchments (Fig. S4). Relationships between temporal variance and flow-weighted mean differed by parameter, with most biologically reactive parameters showing greater variance in 304 subcatchments with low concentrations (Fig. S8). weighted mean concentration from 2004-2007 for most parameters, suggesting stability of the 
spatial structure of water chemistry on decadal timescales (Fig. 6). The high-water sampling

308 in the spring of 2016 was more representative of the 2004-2007 means for all parameters

309 except $\mathrm{NO}_{3}{ }^{-}$. DOC, $\mathrm{PO}_{4}{ }^{3-}$, and $\mathrm{NO}_{2}{ }^{-}$concentrations were lower across most subcatchments in 2015 and 2016, but $\mathrm{NO}_{3}{ }^{-}, \mathrm{Cl}^{-}, \mathrm{SUVA}_{254}$, and $\mathrm{SO}_{4}{ }^{2-}$ showed no systematic change (Fig. 6).

\section{Discussion}

312 Ecohydrologic explanations for observed patterns in variability

While it is widely held that temporal variability is greater in headwater streams due to

314 their size and reactivity (Vannote et al. 1980; Creed et al. 2015), we found that temporal

315 variance did not systematically decrease with catchment size for most parameters, though the range of temporal variances did diminish. Three, non-exclusive phenomena could be contributing to this unexpected preservation of variability: 1. synchronous hydrologic variation among subcatchments, 2. source-patch homogeneity in small subcatchments, and 3. increasing variance from in-stream biogeochemical processes in larger subcatchments. First, water flow determines connectivity between stream and catchment, mediating what landscape components contribute particulate materials and solutes to the stream network at what times. Subsequently, hydrology controls the residence time of those particulates and solutes in different components of the stream network, determining exposure to biogeochemical transformation (Pinay et al. 2015; Abbott et al. 2016; Raymond et al. 2016). Hydrology is

325 also the predominant mode of disturbance in most stream ecosystems (e.g. flood and drought), 326 structuring the ecological community and its capacity to remove or retain carbon and nutrients 327 (Widder et al. 2014; Dong et al. 2017). Consequently, some degree of synchrony is expected 328 in a river system where storm events and changes in evapotranspiration are likely to affect 329 multiple subcatchments near the same time. Moving upstream, the synchrony of hydrologic 330 variability among nearby subcatchments is likely to increase (Hammond \& Kolasa 2014; 
Isaak et al. 2014), potentially counteracting the expected downstream decrease in temporal

332

333

variance. Second, temporal variability could become more distinct upstream of spatial variance thresholds because of larger relative coverage of source or sink patches with distinct ecohydrologic characteristics. Differences in persistence and connectivity of the dominant patch could cause higher or lower temporal variability in small subcatchments. Several ecohydrologic characteristics have been identified that could mediate temporal variance at the spatial scales observed here, including variability in groundwater contribution and specific discharge (Burns et al. 1998; Sivapalan 2003; Lyon et al. 2012) and changes in subsurface contact time (Wolock et al. 1997). Third, in-stream biogeochemical uptake or mineralization of carbon and nutrients could create variability unassociated with source fluctuations, particularly for elements that limit biological activity (Mulholland 2004; McGuire et al. 2014; Dong et al. 2017). Diversity and activity of biological processes become more variable in smaller subcatchments (Alexander et al. 2007; Altermatt 2013; Widder et al. 2014), though the causality of links between biota and water chemistry is not clear. Regardless of the cause, the divergence of temporal variability regimes in small catchments has implications for developing statistical or mechanistic models of ecohydrologic behavior. Models parameterized with data from a single headwater catchment may be misleading given the diversity of the spatial and temporal dynamics even among adjacent headwater streams. Repeat synoptic sampling of nearby subcatchments should be routine at long-term or highfrequency monitoring sites to assure representativeness of time series used in model calibration or scaling.

The spatial patterns of most parameters were stable on decadal timescales, despite large changes in nutrient inputs to these catchments over the 12 years of sampling (Aquilina et al. 2012; Kolbe et al. 2016; Poisvert et al. 2017). One explanation for this unexpected spatial stability could be that subcatchments differ substantially in their resilience to solute 
loading and disturbance. There are myriad characteristics that can alter retention or removal capacity of a subcatchment (Pinay et al. 2015; Kolbe et al. 2016), most of which are not measured or measureable at catchment scales. Ecological parameters that could influence subcatchment resilience include the distribution of preferential flowpaths in soils and aquifers, which determines residence times in different catchment components; the vertical and horizontal distribution of soil properties; differences in biogeochemical activity in the nonsaturated zone or groundwater; land-use history; and heterogeneity in near-surface geology. Because agricultural activity is not randomly distributed across the landscape, some of these same inherent characteristics indirectly control land use and associated nutrient loading and disturbance (Odgaard et al. 2013; Zabel et al. 2014; Thomas et al. 2016). For example, in our study area, differences in soil fertility and surface roughness have resulted in the preferential cultivation of subcatchments underlain by schist, which are also more prone to nutrient export than granitic catchments with thicker soils (Thomas et al. 2016). The combined effect of differences in resilience to nutrient loading and associated differences in disturbance regime could explain the observed spatial stability of water chemistry, and more generally, the breakdown in the relationship between nutrient inputs and outputs at the small catchment scale (Burt \& Pinay 2005; Lefebvre et al. 2007; Brookshire et al. 2009; Schilling et al. 2013).

\section{Implications for monitoring and intervention}

While our methods cannot and do not attempt to quantify annual loads or highfrequency dynamics (Kirchner \& Neal 2013), the high spatial variability observed among small subcatchments coupled with the persistent spatial stability of water quality suggests that occasional synoptic sampling of subcatchments can provide valuable information for catchment characterization and management. Specifically, knowing the spatial structure of water quality and the typical grain size of source and sink patches in the landscape could 
improve site selection for monitoring, restoration, and conservation efforts. Interventions

381

382

383

384

385

386

387

388

389

390

391

392

393

394

395

396

397

398

399

400

401

402

403

applied at spatial scales larger than the variance threshold for the parameter of concern, where subcatchment size is much larger than the grain size of the pollutant drivers and sinks, would be suboptimal at best (treating non-offending areas) and at worst could unnecessarily disturb ecosystems or human activity.

For parameters with high spatial stability, synoptic sampling can allow targeted intervention in the subcatchments with highest leverage, potentially yielding catchment-level improvements (Heathwaite 2010; Liu et al. 2016; Roley et al. 2016). Conversely, efforts to quantify loads with high-frequency monitoring would be most effective downstream of variance thresholds, where the channel integrates multiple patches. While these locations will underestimate the amplitude of temporal variability compared to the most dynamic smaller subcatchments (Temnerud et al. 2010), this bias is not necessarily greater than randomly selecting a subcatchment upstream of the variance threshold, where temporal variability could be much lower than at the catchment outflow (Figs. 3, S2).

In catchments where water quality shows little correlation with observed land use (as is the case here), redistribution of agricultural activity based on subcatchment leverage could improve outflow water chemistry without decreasing agricultural yields. Aligning agricultural activity with subcatchment resilience could improve water quality even in the absence of mechanistic understanding of the proximate causes of that resilience (Musolff et al. 2015; Thomas et al. 2016). While this approach is not socioeconomically feasible in areas where agricultural activity is at capacity (Li et al. 2014), it could optimize land management choices where the extent or intensity of agricultural activity are changing, such as much of the developing world or areas of rural exodus (Thomas et al. 2016). We emphasize that when differences in subcatchment water quality are due to unmeasured differences in land use (e.g. 
nutrient loading or disturbance) rather than subcatchment resilience to nutrient loading, blind redistribution of agricultural activity could have unforeseen consequences, degrading water quality in previously pristine subcatchments with no net improvement in catchment-level water quality.

Testing the generality of subcatchment leverage, synchrony, and spatial stability We do not propose that the specific patterns of spatiotemporal variability observed here are general, and we recognize that our conceptual framework needs to be tested with more complete spatial time series of both chemistry and discharge in diverse environments. Spatial stability and synchrony of water chemistry likely differ by biome (Krause et al. 2014; Jantze et al. 2015), though evidence from relatively pristine catchments in temperate (Asano et al. 2009; Zimmer et al. 2013), boreal (Temnerud \& Bishop 2005), and desert (Fisher et al. 1982; Dong et al. 2017) regions suggest that the patterns observed here are not unique to agricultural ecosystems. Generally, we predict that ecosystems with less hydrologic variability will show greater chemical stability, while ecosystems with more pronounced seasonal or event-level hydrologic shifts will experience more reorganizations of subcatchment chemistry due to changes in source area, residence time, and flowpath (Godsey \& Kirchner 2014). Likewise, because topography systematically influences vegetation, soil conditions, hydrology, and human activity (Duncan et al. 2013; Thomas et al. 2016), we expect topographic heterogeneity to reduce spatial variance thresholds, creating smaller but more distinct source and sink patches, and less stable spatial patterns. We also predict that limiting nutrients will have less spatial stability than non-limiting nutrients (Mulholland 2004; Doyle 2005; Dong et al. 2017), which are more evenly distributed in the landscape and less influenced by in-stream processes (Basu et al. 2010). However, there are plausible mechanisms that could counteract some of these predicted patterns. For example, synchrony 
may be higher in ecosystems with greater hydrologic variability, and spatial stability could be greater in heterogeneous landscapes where absolute differences in concentration among subcatchments are larger. Indeed, the lack of correlation between spatial stability and synchrony observed here suggests that the magnitude of concentration differences between subcatchments strongly influences the representativeness of synoptic sampling. On a basic level, quantifying variance thresholds, spatial stability, and synchrony in contrasting ecosystems could elucidate links between spatial and temporal variability (Hammond \& Kolasa 2014) to generate general understanding of how water, carbon, and nutrients move through freshwater landscapes (Ward et al. 2017) and cost-effectively inform management decisions in developing and developed countries.

As a final note, we point out that this variance-partitioning approach in no way supplants the need for detailed, high-frequency investigation of concentration and flux 440 dynamics at multiple scales (Isaak et al. 2014; Blaen et al. 2016; Ruhala \& Zarnetske 2017).

441 Such studies identify mechanisms ultimately responsible for the temporal and spatial variability revealed by periodic synoptic sampling. The growing number of tools for interpreting and predicting water chemistry in stream networks (Hirsch et al. 2010; McGuire

444 et al. 2014) together with increasingly accessible historical datasets (Burt et al. 2011;

445 Kirchner \& Neal 2013) are laying the foundation for inter-catchment comparisons of 446 spatiotemporal dynamics, potentially moving ecohydrology beyond descriptions of site447 specific heterogeneity (McDonnell et al. 2007; Krause et al. 2014; Abbott et al. 2016). To this 448 end, the simple analyses presented here could be widely tested with existing high, medium, or 449 low frequency datasets, including those unsuitable for other network-scale analyses (Hoef et 450 al. 2006; Isaak et al. 2014; McGuire et al. 2014). The interpretation of periodic synoptic 451 sampling in a framework of subcatchment leverage, synchrony, and spatial stability could 452 complement high-frequency studies to improve management of socioecological systems and 
453 address problems that do not respect disciplinary boundaries between ecology, hydrology, and 454 sociology.

455 
457 This project has been funded by the European Union’s Seventh Framework Program for 458 research, technological development and demonstration under grant agreement no.

459607150 (FP7-PEOPLE-2013-ITN - INTERFACES - Ecohydrological interfaces as critical 460 hotspots for transformations of ecosystem exchange fluxes and biogeochemical cycling). B.

461 Abbott and G. Pinay were also supported by the French EC2CO grant "Caractérisation 462 hydrologique et biogéochimique de la dénitrification dans les paysages.” We thank P. 463 Petitjean for data management.

464 
466

467

468

469

470

471

472

473

474

475

476

477

478

479

480

481

482

483

484

485

486

487

488

489

490

491

492

493

494

495

496

497

498

499

500

501

502

503

504

Abbott, B.W., Baranov, V., Mendoza-Lera, C., Nikolakopoulou, M., Harjung, A., Kolbe, T., et al. (2016). Using multi-tracer inference to move beyond single-catchment ecohydrology. Earth-Sci. Rev., 160, 19-42.

Alexander, R.B., Boyer, E.W., Smith, R.A., Schwarz, G.E. \& Moore, R.B. (2007). The Role of Headwater Streams in Downstream Water Quality. J. Am. Water Resour. Assoc., 43, 4159.

Altermatt, F. (2013). Diversity in riverine metacommunities: a network perspective. Aquat. Ecol., 47, 365-377.

Andreen, W.L. (2004). Water Quality Today - Has the Clean Water Act Been a Success? (SSRN Scholarly Paper No. ID 554803). Social Science Research Network, Rochester, NY.

Aquilina, L., Vergnaud-Ayraud, V., Labasque, T., Bour, O., Molénat, J., Ruiz, L., et al. (2012). Nitrate dynamics in agricultural catchments deduced from groundwater dating and long-term nitrate monitoring in surface e gnoundwaters. Sci. Total Environ., 435-436, 167-178.

Asano, Y., Uchida, T., Mimasu, Y. \& Ohte, N. (2009). Spatial patterns of stream solute concentrations in a steep mountainous catchment with a homogeneous landscape. Water Resour. Res., 45, W10432.

Basu, N.B., Destouni, G., Jawitz, J.W., Thompson, S.E., Loukinova, N.V., Darracq, A., et al. (2010). Nutrient loads exported from managed catchments reveal emergent biogeochemical stationarity. Geophys. Res. Lett., 37, L23404.

Bishop, K., Buffam, I., Erlandsson, M., Fölster, J., Laudon, H., Seibert, J., et al. (2008). Aqua Incognita: the unknown headwaters. Hydrol. Process., 22, 1239-1242.

Blaen, P.J., Khamis, K., Lloyd, C.E.M., Bradley, C., Hannah, D. \& Krause, S. (2016). Realtime monitoring of nutrients and dissolved organic matter in rivers: Capturing event dynamics, technological opportunities and future directions. Sci. Total Environ., 569-570, 647-660.

Blöschl, G., Grayson, R.B. \& Sivapalan, M. (1995). On the representative elementary area (REA) concept and its utility for distributed rainfall-runoff modelling. Hydrol. Process., 9, 313-330.

Brookshire, E.N.J., Valett, H.M. \& Gerber, S. (2009). Maintenance of terrestrial nutrient loss signatures during in-stream transport. Ecology, 90, 293-299.

Burns, D.A., Murdoch, P.S., Lawrence, G.B. \& Michel, R.L. (1998). Effect of groundwater springs on NO3- concentrations during summer in Catskill Mountain streams. Water Resour. Res., 34, 1987-1996.

Burt, T.P., Howden, N.J.K., Worrall, F. \& McDonnell, J.J. (2011). On the value of long-term, low-frequency water quality sampling: avoiding throwing the baby out with the bathwater. Hydrol. Process., 25, 828-830.

Burt, T.P. \& Pinay, G. (2005). Linking hydrology and biogeochemistry in complex landscapes. Prog. Phys. Geogr., 29, 297-316. 

(1998). Nonpoint Pollution of Surface Waters with Phosphorus and Nitrogen. Ecol. Appl., 8, 559-568.

Chapin, F.S., Shaver, G.R., Giblin, A.E., Nadelhoffer, K.J. \& Laundre, J.A. (1995). Responses of Arctic Tundra to Experimental and Observed Changes in Climate. Ecology, 76, 694.

Chapin, F.S., Woodwell, G.M., Randerson, J.T., Rastetter, E.B., Lovett, G.M., Baldocchi, D.D., et al. (2006). Reconciling Carbon-cycle Concepts, Terminology, and Methods. Ecosystems, 9, 1041-1050.

Creed, I.F., McKnight, D.M., Pellerin, B.A., Green, M.B., Bergamaschi, B.A., Aiken, G.R., et al. (2015). The river as a chemostat: fresh perspectives on dissolved organic matter flowing down the river continuum. Can. J. Fish. Aquat. Sci., 72, 1272-1285.

Davis, J., Sim, L. \& Chambers, J. (2010). Multiple stressors and regime shifts in shallow aquatic ecosystems in antipodean landscapes. Freshw. Biol., 55, 5-18.

Dent, C.L. \& Grimm, N.B. (1999). Spatial Heterogeneity of Stream Water Nutrient Concentrations Over Successional Time. Ecology, 80, 2283-2298.

Dong, X., Ruhí, A. \& Grimm, N.B. (2017). Evidence for self-organization in determining spatial patterns of stream nutrients, despite primacy of the geomorphic template. Proc. Natl. Acad. Sci., 114, E4744-E4752.

Downing, J. (2012). Global abundance and size distribution of streams and rivers. Inland Waters, 2, 229-236.

Doyle, M.W. (2005). Incorporating hydrologic variability into nutrient spiraling. J. Geophys. Res. Biogeosciences, 110, G01003.

Duncan, J.M., Groffman, P.M. \& Band, L.E. (2013). Towards closing the watershed nitrogen budget: Spatial and temporal scaling of denitrification. J. Geophys. Res. Biogeosciences, 118, 1105-1119.

Dupas, R., Jomaa, S., Musolff, A., Borchardt, D. \& Rode, M. (2016). Disentangling the influence of hydroclimatic patterns and agricultural management on river nitrate dynamics from sub-hourly to decadal time scales. Sci. Total Environ., 571, 791-800.

Erlandsson, M., Buffam, I., Fölster, J., Laudon, H., Temnerud, J., Weyhenmeyer, G.A., et al. (2008). Thirty-five years of synchrony in the organic matter concentrations of Swedish rivers explained by variation in flow and sulphate. Glob. Change Biol., 14, 1191-1198.

539 Foley, J.A., Ramankutty, N., Brauman, K.A., Cassidy, E.S., Gerber, J.S., Johnston, M., et al. 540 (2011). Solutions for a cultivated planet. Nature, 478, 337-342.

541 Gascuel-Odoux, C., Aurousseau, P., Durand, P., Ruiz, L. \& Molenat, J. (2010). The role of 542 climate on inter-annual variation in stream nitrate fluxes and concentrations. Sci. Total 543 Environ., Special Section: Integrating Water and Agricultural Management Under Climate 544 Change, 408, 5657-5666.

Godsey, S.E. \& Kirchner, J.W. (2014). Dynamic, discontinuous stream networks: hydrologically driven variations in active drainage density, flowing channels and stream order. Hydrol. Process., 28, 5791-5803. 
Gruber, N. \& Galloway, J.N. (2008). An Earth-system perspective of the global nitrogen cycle. Nature, 451, 293-296.

550 Gundry, S., Wright, J. \& Conroy, R. (2004). A systematic review of the health outcomes related to household water quality in developing countries. J. Water Health, 2, 1-13.

Hammond, M.P. \& Kolasa, J. (2014). Spatial Variation as a Tool for Inferring Temporal Variation and Diagnosing Types of Mechanisms in Ecosystems. PLOS ONE, 9, e89245.

Haygarth, P.M., Condron, L.M., Heathwaite, A.L., Turner, B.L. \& Harris, G.P. (2005). The phosphorus transfer continuum: Linking source to impact with an interdisciplinary and multiscaled approach. Sci. Total Environ., Linking Landscape Sources of Phosphorus and Sediment to Ecological Impacts in Surface WatersHaygarth S.I., 344, 5-14.

Heathwaite, A.L. (2010). Multiple stressors on water availability at global to catchment scales: understanding human impact on nutrient cycles to protect water quality and water availability in the long term. Freshw. Biol., 55, 241-257.

Hering, D., Borja, A., Carstensen, J., Carvalho, L., Elliott, M., Feld, C.K., et al. (2010). The European Water Framework Directive at the age of 10: A critical review of the achievements with recommendations for the future. Sci. Total Environ., 408, 4007-4019.

Hirsch, R.M., Moyer, D.L. \& Archfield, S.A. (2010). Weighted Regressions on Time, Discharge, and Season (WRTDS), with an Application to Chesapeake Bay River Inputs. $J$. Am. Water Resour. Assoc., 46, 857-880.

Hoef, J.M.V., Peterson, E. \& Theobald, D. (2006). Spatial statistical models that use flow and stream distance. Environ. Ecol. Stat., 13, 449-464.

Horne, J.K. \& Schneider, D.C. (1995). Spatial Variance in Ecology. Oikos, 74, 18-26.

Howarth, R.W. (2008). Coastal nitrogen pollution: A review of sources and trends globally and regionally. Harmful Algae, HABs and Eutrophication, 8, 14-20.

Isaak, D.J., Peterson, E.E., Ver Hoef, J.M., Wenger, S.J., Falke, J.A., Torgersen, C.E., et al. (2014). Applications of spatial statistical network models to stream data: Spatial statistical network models for stream data. Wiley Interdiscip. Rev. Water, 1, 277-294. algorithm for optimal partitioning of data on an interval. IEEE Signal Process. Lett., 12, 105108. Organic and Inorganic Carbon in Subarctic Headwater Streams. Arct. Antarct. Alp. Res., 47, 529-546.

583

Jarvie, H.P., Sharpley, A.N., Withers, P.J.A., Scott, J.T., Haggard, B.E. \& Neal, C. (2013). Phosphorus Mitigation to Control River Eutrophication: Murky Waters, Inconvenient Truths, and "Postnormal” Science. J. Environ. Qual., 42, 295-304.

Jenny, J.-P., Normandeau, A., Francus, P., Taranu, Z.E., Gregory-Eaves, I., Lapointe, F., et al. (2016). Urban point sources of nutrients were the leading cause for the historical spread of hypoxia across European lakes. Proc. Natl. Acad. Sci., 201605480.

587 Jordan, T.E., Correll, D.L. \& Weller, D.E. (1997). Relating nutrient discharges from 588 watersheds to land use and streamflow variability. Water Resour. Res., 33, 2579-2590. 
Karlsen, R.H., Grabs, T., Bishop, K., Buffam, I., Laudon, H. \& Seibert, J. (2016). Landscape controls on spatiotemporal discharge variability in a boreal catchment. Water Resour. Res., 591 52, 6541-6556.

592 Kaufmann, P.R., Herlihy, A.T., Mitch, M.E., Messer, J.J. \& Overton, W.S. (1991). Stream 593 chemistry in the eastern United States: 1. Synoptic survey design, acid-base status, and 594 regional patterns. Water Resour. Res., 27, 611-627.

595 Killick, R., Fearnhead, P. \& Eckley, I.A. (2012). Optimal detection of changepoints with a 596 linear computational cost. J. Am. Stat. Assoc., 107, 1590-1598.

597

598

599

600

601

602

603

604

605

606

607

608

609

610

611

612

613

614

615

616

617

618

619

620

621

622

623

624

625

626

627

628

629

630

631

Kirchner, J.W., Feng, X., Neal, C. \& Robson, A.J. (2004). The fine structure of water-quality dynamics: the (high-frequency) wave of the future. Hydrol. Process., 18, 1353-1359.

Kirchner, J.W. \& Neal, C. (2013). Universal fractal scaling in stream chemistry and its implications for solute transport and water quality trend detection. Proc. Natl. Acad. Sci., 110, 12213-12218.

Kolbe, T., Marçais, J., Thomas, Z., Abbott, B.W., de Dreuzy, J.-R., Rousseau-Gueutin, P., et al. (2016). Coupling 3D groundwater modeling with CFC-based age dating to classify local groundwater circulation in an unconfined crystalline aquifer. J. Hydrol., 543, Part A, 31-46.

Krause, S., Freer, J., Hannah, D.M., Howden, N.J.K., Wagener, T. \& Worrall, F. (2014). Catchment similarity concepts for understanding dynamic biogeochemical behaviour of river basins. Hydrol. Process., 28, 1554-1560.

Lefebvre, S., Clément, J.-C., Pinay, G., Thenail, C., Durand, P. \& Marmonier, P. (2007). 15nnitrate signature in low-order streams: effects of land cover and agricultural practices. Ecol. Appl., 17, 2333-2346.

Li, Y., Yang, X., Cai, H., Xiao, L., Xu, X. \& Liu, L. (2014). Topographical Characteristics of Agricultural Potential Productivity during Cropland Transformation in China. Sustainability, 7, 96-110.

Liu, J. \& Yang, W. (2012). Water sustainability for China and beyond. Science, 337, 649650 .

Liu, R., Xu, F., Zhang, P., Yu, W. \& Men, C. (2016). Identifying non-point source critical source areas based on multi-factors at a basin scale with SWAT. J. Hydrol., 533, 379-388.

Lowe, W.H., Likens, G.E. \& Power, M.E. (2006). Linking Scales in Stream Ecology. BioScience, 56, 591-597.

Lyon, S.W., Nathanson, M., Spans, A., Grabs, T., Laudon, H., Temnerud, J., et al. (2012). Specific discharge variability in a boreal landscape. Water Resour. Res., 48, W08506.

McDonnell, J.J. \& Beven, K. (2014). Debates-The future of hydrological sciences: A (common) path forward? A call to action aimed at understanding velocities, celerities and residence time distributions of the headwater hydrograph. Water Resour. Res., 50, 53425350.

McDonnell, J.J., Sivapalan, M., Vaché, K., Dunn, S., Grant, G., Haggerty, R., et al. (2007). Moving beyond heterogeneity and process complexity: A new vision for watershed hydrology. Water Resour. Res., 43, W07301.

McGuire, K.J., Torgersen, C.E., Likens, G.E., Buso, D.C., Lowe, W.H. \& Bailey, S.W. (2014). Network analysis reveals multiscale controls on streamwater chemistry. Proc. Natl. Acad. Sci., 111, 7030-7035. 
Medde, E.T., Berthier, L., Bardy, M., Chenu, J.P., Guzmova, L., Laroche, B., et al. (2014). Enveloppes des milieux potentiellement humides de la France métropolitaine. Programme de modélisation des milieux potentiellement humides de France. Ministère d’Ecologie, du Développement Durable et de l'Energie, Rennes, France.

636 Meter, K.J.V., Basu, N.B., Veenstra, J.J. \& Burras, C.L. (2016). The nitrogen legacy: emerging evidence of nitrogen accumulation in anthropogenic landscapes. Environ. Res. Lett., $63811,035014$.

639

640

641

642

643

644

645

646

647

648

649

650

651

652

653

654

655

656

657

658

659

660

661

662

663

664

665

666

667

668

669

670

671

672

673

674

Moatar, F., Abbott, B.W., Minaudo, C., Curie, F. \& Pinay, G. (2017). Elemental properties, hydrology, and biology interact to shape concentration-discharge curves for carbon, nutrients, sediment, and major ions. Water Resour. Res., 53, 1270-1287.

Mulholland, P.J. (2004). The importance of in-stream uptake for regulating stream concentrations and outputs of $\mathrm{N}$ and $\mathrm{P}$ from a forested watershed: evidence from long-term chemistry records for Walker Branch Watershed. Biogeochemistry, 70, 403-426.

Musolff, A., Schmidt, C., Selle, B. \& Fleckenstein, J.H. (2015). Catchment controls on solute export. Adv. Water Resour., 86, 133-146.

Odgaard, M.V., Bøcher, P.K., Dalgaard, T., Moeslund, J.E. \& Svenning, J.-C. (2013). Human-driven topographic effects on the distribution of forest in a flat, lowland agricultural region. J. Geogr. Sci., 24, 76-92.

Omernik, J.M., Abernathy, A.R. \& Male, L.M. (1981). Stream nutrient levels and proximity of agricultural and forest land to streams: Some relationships. J. Soil Water Conserv., 36, 227-231.

Perrot, T., Rossi, N., Ménesguen, A. \& Dumas, F. (2014). Modelling green macroalgal blooms on the coasts of Brittany, France to enhance water quality management. J. Mar. Syst., 132, 38-53.

Pinay, G., Peiffer, S., De Dreuzy, J.-R., Krause, S., Hannah, D.M., Fleckenstein, J.H., et al. (2015). Upscaling Nitrogen Removal Capacity from Local Hotspots to Low Stream Orders' Drainage Basins. Ecosystems, 18, 1101-1120.

Poisvert, C., Curie, F. \& Moatar, F. (2017). Annual agricultural N surplus in France over a 70-year period. Nutr. Cycl. Agroecosystems, 107, 63-78.

R Core Team. (2016). R: A language and environment for statistical computing. R Foundation for Statistical Computing,. Vienna, Austria.

Raymond, P.A., Saiers, J.E. \& Sobczak, W.V. (2016). Hydrological and biogeochemical controls on watershed dissolved organic matter transport: pulse-shunt concept. Ecology, 97, 5-16.

Reed, D.C. \& Harrison, J.A. (2016). Linking nutrient loading and oxygen in the coastal ocean: A new global scale model. Glob. Biogeochem. Cycles, 30, 2015 GB005303.

Rinaldo, A., Rodriguez-Iturbe, I. \& Rigon, R. (1998). Channel networks. Annu. Rev. Earth Planet. Sci., 26, 289-327.

Roley, S.S., Tank, J.L., Tyndall, J.C. \& Witter, J.D. (2016). How cost-effective are cover crops, wetlands, and two-stage ditches for nitrogen removal in the Mississippi River Basin? Water Resour. Econ., 15, 43-56.

Ruhala, S.S. \& Zarnetske, J.P. (2017). Using in-situ optical sensors to study dissolved organic carbon dynamics of streams and watersheds: A review. Sci. Total Environ., 575, 713-723. 
677 Seitzinger, S.P., Mayorga, E., Bouwman, A.F., Kroeze, C., Beusen, A.H.W., Billen, G., et al. (2010). Global river nutrient export: A scenario analysis of past and future trends. Glob. 679 Biogeochem. Cycles, 24, GB0A08.

680 Shaman, J., Stieglitz, M. \& Burns, D. (2004). Are big basins just the sum of small 681 catchments? Hydrol. Process., 18, 3195-3206.

682 Sivapalan, M. (2003). Process complexity at hillslope scale, process simplicity at the 683 watershed scale: is there a connection? Hydrol. Process., 17, 1037-1041.

684 Sutton, M.A. \& UNEP (Eds.). (2013). Our nutrient world: the challenge to produce more

685

686

687

688

689

690

691

692

693

694

695

696

697

698

699

700

701

702

703

704

705

706

707

708

709

710

711

712

713

714

715

716

food and energy with less pollution; [global overview on nutrient management]. Centre for Ecology \& Hydrology, Edinburgh.

Temnerud, J. \& Bishop, K. (2005). Spatial Variation of Streamwater Chemistry in Two Swedish Boreal Catchments:? Implications for Environmental Assessment. Environ. Sci. Technol., 39, 1463-1469.

Temnerud, J., Fölster, J., Buffam, I., Laudon, H., Erlandsson, M. \& Bishop, K. (2010). Can the distribution of headwater stream chemistry be predicted from downstream observations? Hydrol. Process., 24, 2269-2276.

Thomas, Z., Abbott, B.W., Troccaz, O., Baudry, J. \& Pinay, G. (2016). Proximate and ultimate controls on carbon and nutrient dynamics of small agricultural catchments. Biogeosciences, 13, 1863-1875.

Turner, M.G., Dale, V.H. \& Gardner, R.H. (1989). Predicting across scales: theory development and testing. Landsc. Ecol., 3, 245-252.

Vannote, R.L., Minshall, G.W., Cummins, K.W., Sedell, J.R. \& Cushing, C.E. (1980). The river continuum concept. Can. J. Fish. Aquat. Sci., 37, 130-137.

Vörösmarty, C.J., McIntyre, P.B., Gessner, M.O., Dudgeon, D., Prusevich, A., Green, P., et al. (2010). Global threats to human water security and river biodiversity. Nature, 467, 555561.

Ward, N.D., Bianchi, T.S., Medeiros, P.M., Seidel, M., Richey, J.E., Keil, R.G., et al. (2017). Where Carbon Goes When Water Flows: Carbon Cycling across the Aquatic Continuum. Front. Mar. Sci., 4.

Weishaar, J.L., Aiken, G.R., Bergamaschi, B.A., Fram, M.S., Fujii, R. \& Mopper, K. (2003). Evaluation of Specific Ultraviolet Absorbance as an Indicator of the Chemical Composition and Reactivity of Dissolved Organic Carbon. Environ. Sci. Technol., 37, 4702-4708.

White, M.J., Storm, D.E., Busteed, P.R., Stoodley, S.H. \& Phillips, S.J. (2009). Evaluating Nonpoint Source Critical Source Area Contributions at the Watershed Scale. J. Environ. Qual., 38, 1654.

Widder, S., Besemer, K., Singer, G.A., Ceola, S., Bertuzzo, E., Quince, C., et al. (2014). Fluvial network organization imprints on microbial co-occurrence networks. Proc. Natl. Acad. Sci., 111, 12799-12804.

Withers, P.J.A., Neal, C., Jarvie, H.P. \& Doody, D.G. (2014). Agriculture and Eutrophication: Where Do We Go from Here? Sustainability, 6, 5853-5875. 
717 Wolock, D.M., Fan, J. \& Lawrence, G.B. (1997). Effects of basin size on low-flow stream 718 chemistry and subsurface contact time in the Neversink River watershed, New York. Hydrol. 719 Process., 11, 1273-1286.

720 Zabel, F., Putzenlechner, B. \& Mauser, W. (2014). Global Agricultural Land Resources - A 721 High Resolution Suitability Evaluation and Its Perspectives until 2100 under Climate Change 722 Conditions. PLOS ONE, 9.

723 Zimmer, M.A., Bailey, S.W., McGuire, K.J. \& Bullen, T.D. (2013). Fine scale variations of 724 surface water chemistry in an ephemeral to perennial drainage network. Hydrol. Process., 27, 725 3438-3451.

726

727 
A
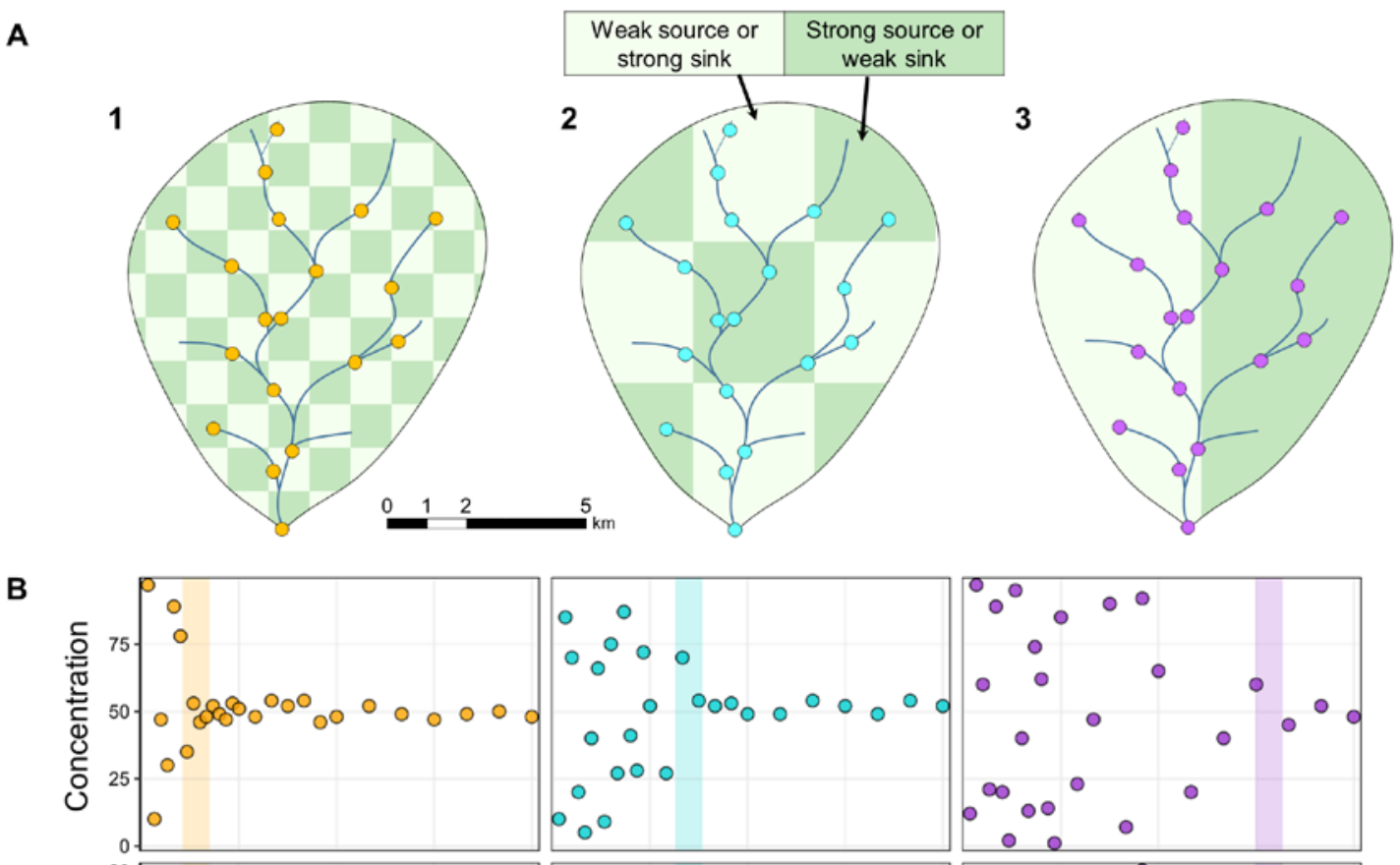

C

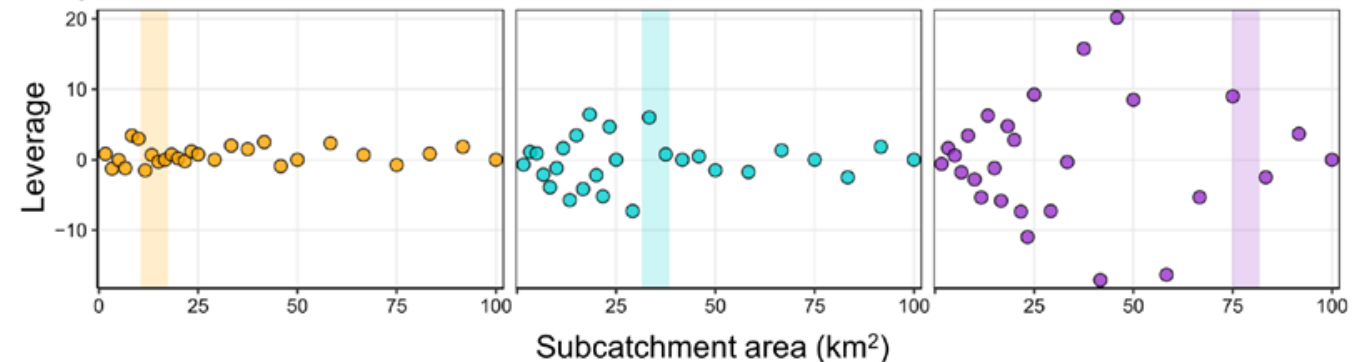

Subcatchment area $\left(\mathrm{km}^{2}\right)$

730 Figure 1. Example patterns of stream network chemistry for three hypothetical solutes 731 distributed in equal quantity to the same $100 \mathrm{~km}^{2}$ catchment. A) The distribution of solute sources is represented by shading, where darker patches are strong net sources (100) and lighter patches make no net contribution (0). B) Simulated solute concentrations at the subcatchment sampling points based on the upstream distribution of solute sources. Though the three solutes have the same concentration at the catchment outlet, differences in source patch size alter the location of the collapse of spatial variance, represented by the vertical colored bars. C) The leverage of each subcatchment on catchment outflow concentration (Equation 1). Influence or leverage of a subcatchment on outlet chemistry depends on subcatchment discharge and difference from the outlet concentration. Note that in a real catchment the variance threshold for a given solute depends on the interaction between patch size, location, and strength, and the temporally dynamic extent of the hydrologic network including subsurface flowpaths. Quantifying the variance threshold could just as well reveal the grain size of retention or removal patches as source patches, since the same pattern would be expected for a system with a homogeneous solute source (e.g. atmospheric deposition or 
Asynchronous

Synchronous

A

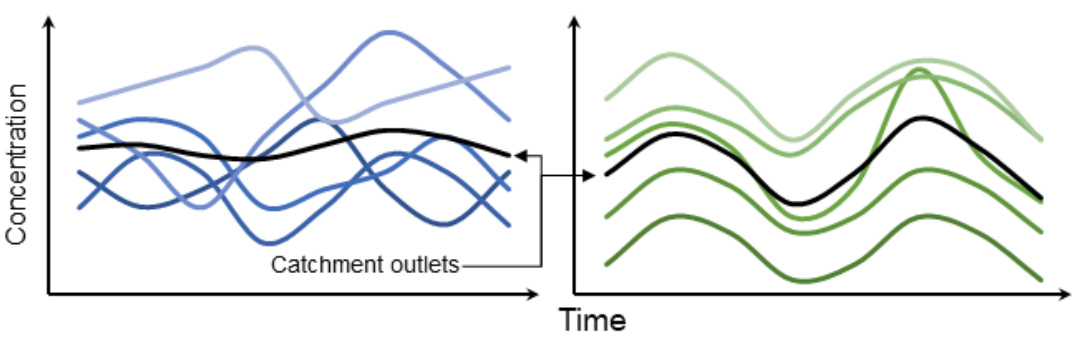

B

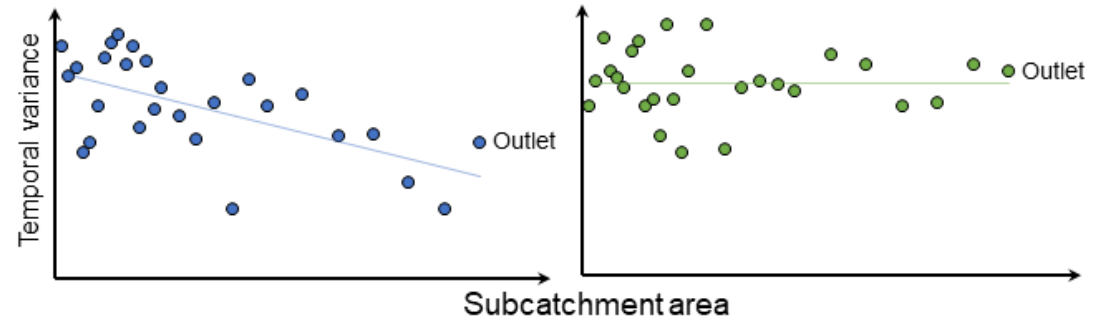

C

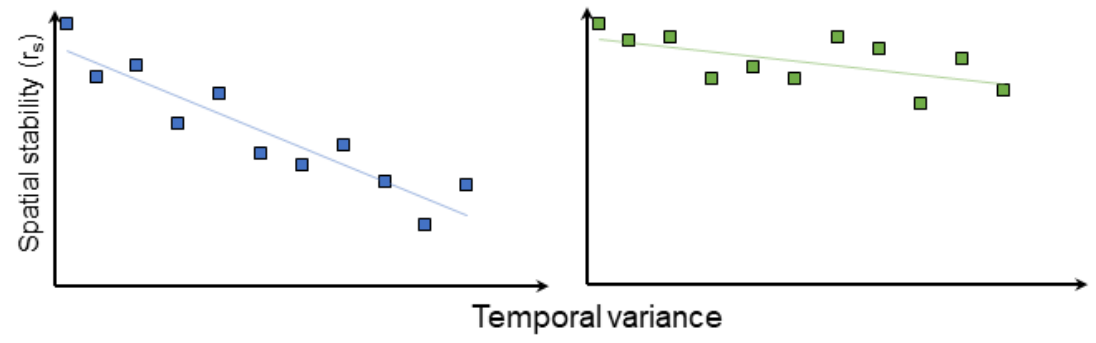

Figure 2. Synchrony among subcatchments determines expected patterns of spatial and temporal variability in water chemistry. A) Temporal change in concentration of a solute for five subcatchments of an asynchronous and synchronous catchment. Asynchronous subcatchments show little temporal covariance, while the synchronous subcatchments show complete covariance. B) The temporal coefficient of variation (CV) for a larger set of nested subcatchments in the two catchments. For the asynchronous catchment, temporal variance decreases moving downstream due to destructive interference of chemical signals, while there is no change in variance in the synchronous catchment. C) The predicted relationship between temporal variability $(\mathrm{CV})$ and spatial stability (the rank correlation $\left(\mathrm{r}_{\mathrm{s}}\right)$ between an individual sampling and the long-term flow-weighted mean or flux) for multiple asynchronous and synchronous catchments. In the asynchronous catchments, the representativeness of a snapshot sampling (spatial stability) decreases strongly with temporal variability (CV) due to reshuffling of subcatchment rank. In highly synchronous catchments, spatial stability is more resilient to temporal variation. 
A

Concentration (scaled)
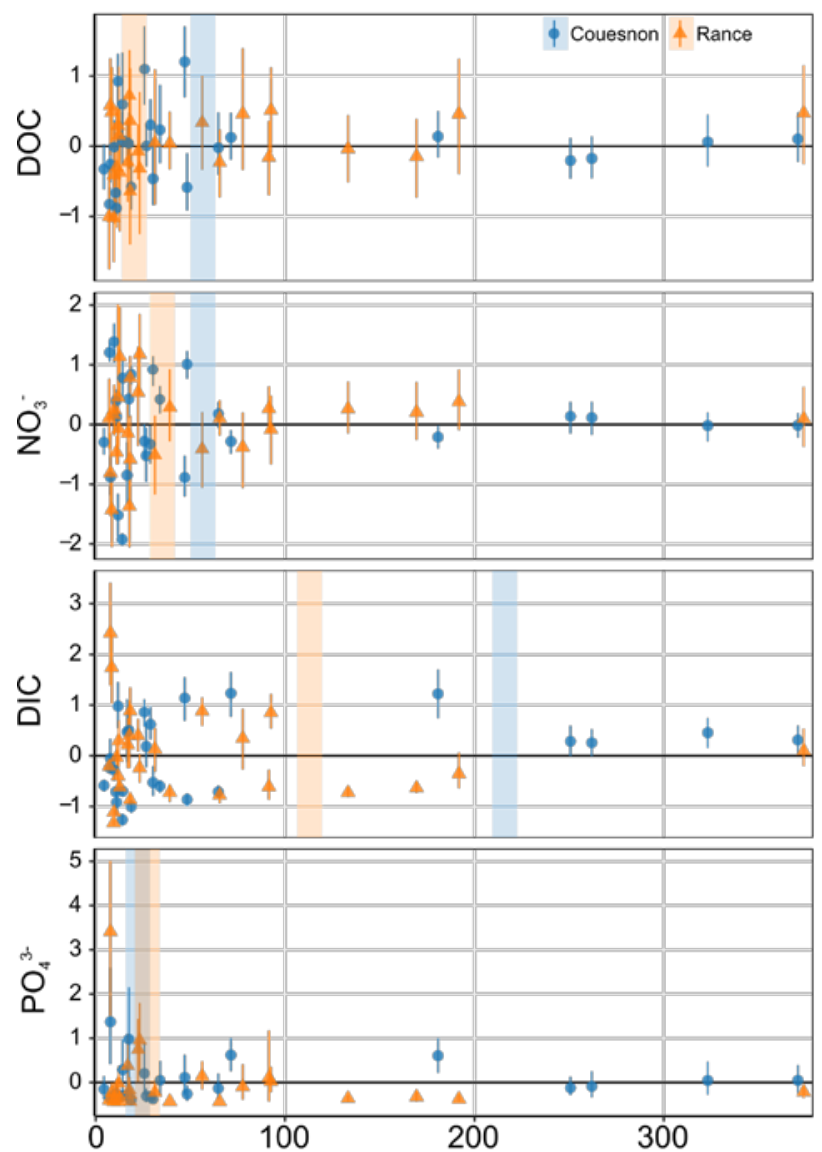

B Temporal variance (scaled CV)
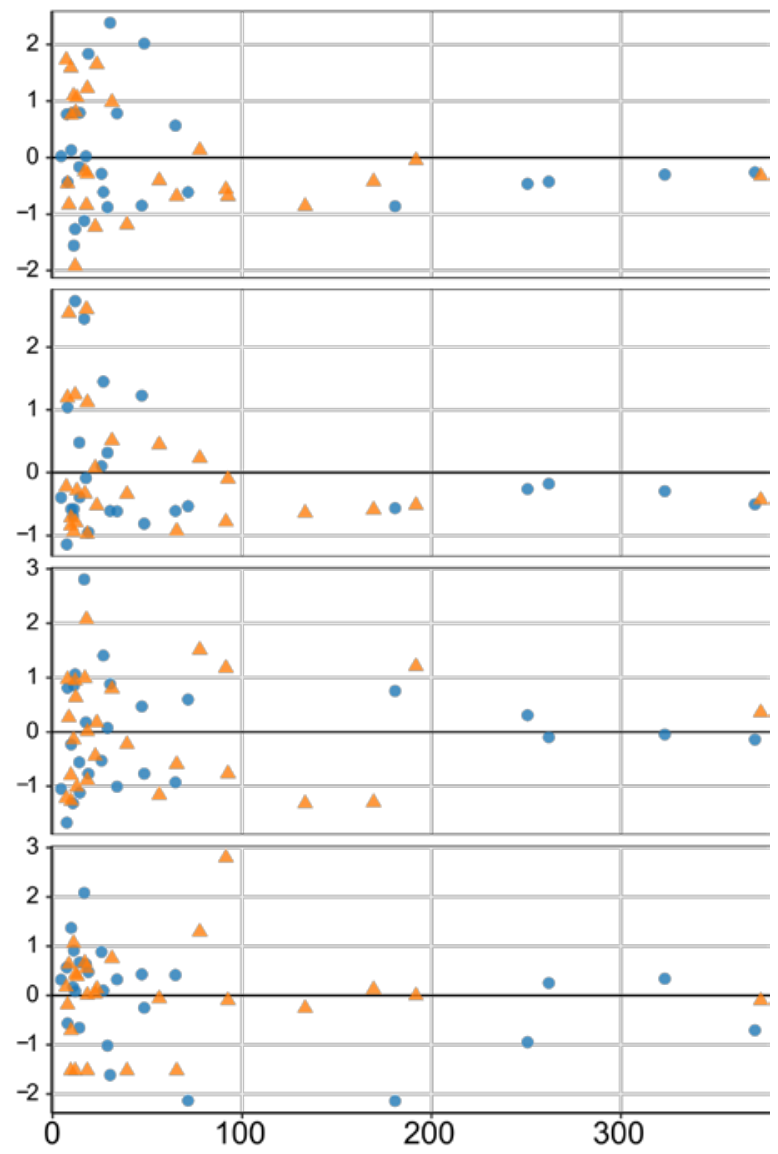

763

Catchment area $\left(\mathrm{km}^{2}\right)$

Figure 3. Variability in concentration and temporal variance for subcatchments of differing sizes in the Couesnon (blue) and Rance (orange) catchments. A) Scaled, flow-weighted mean values for dissolved organic carbon (DOC), nitrate $\left(\mathrm{NO}_{3}{ }^{-}\right)$, dissolved inorganic carbon (DIC), and phosphate $\left(\mathrm{PO}_{4}{ }^{3-}\right.$ ) from 26 Couesnon subcatchments and 30 Rance subcatchments (Fig. S1). Error bars represent bootstrapped non-parametric 95\% confidence intervals of the scaled, flow-weighted mean for repeat samples from each subcatchment ( $n=6$ for Rance, $n=18$ for Couesnon). The vertical colored bands represent statistical changes in spatial variance among subcatchments based on change point analysis implemented for each catchment separately. B) The relationship between temporal variability (scaled CV of repeat samplings for each subcatchment) and catchment size. Concentrations and CVs for each catchment were scaled by subtracting the mean and dividing by the standard deviation to facilitate comparison of changes in variance and evaluate convergence towards the catchment mean ( 0 on the Y-axis). 
A

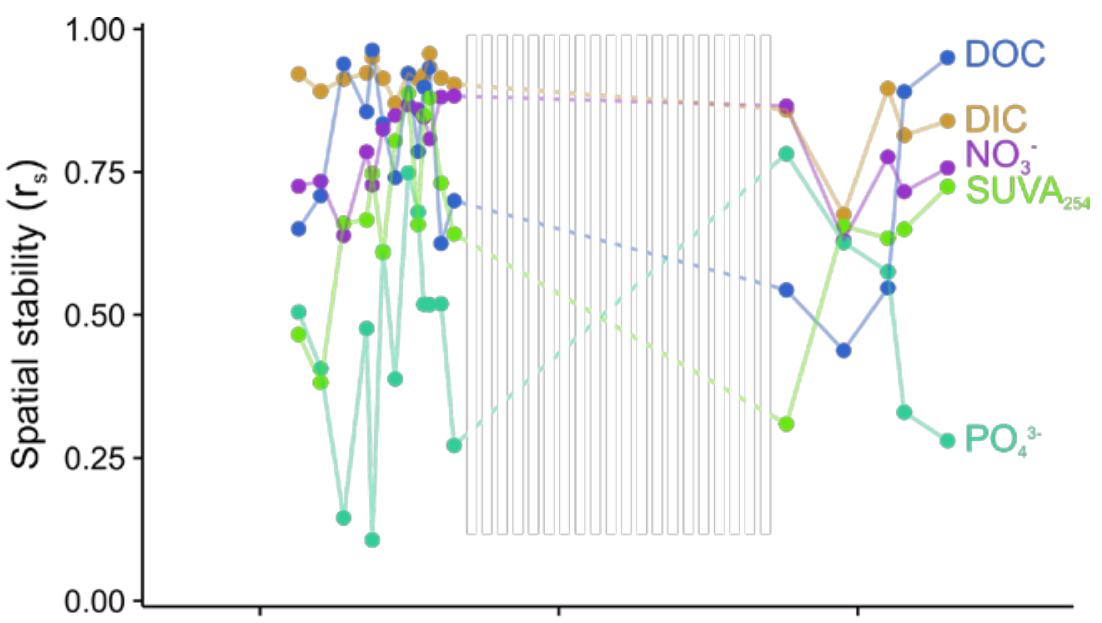

B

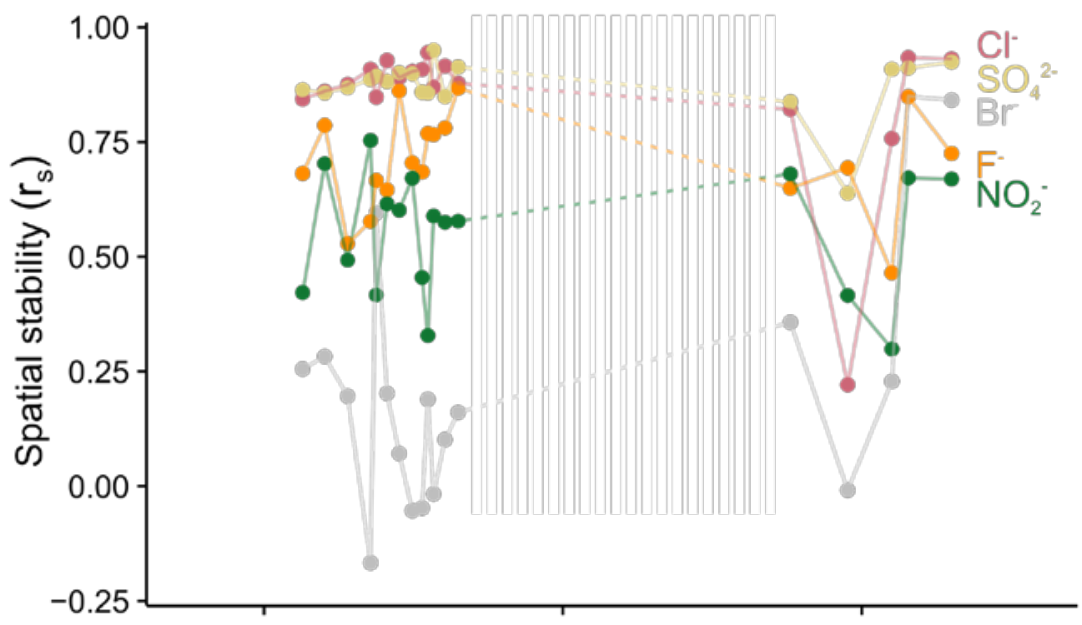

C

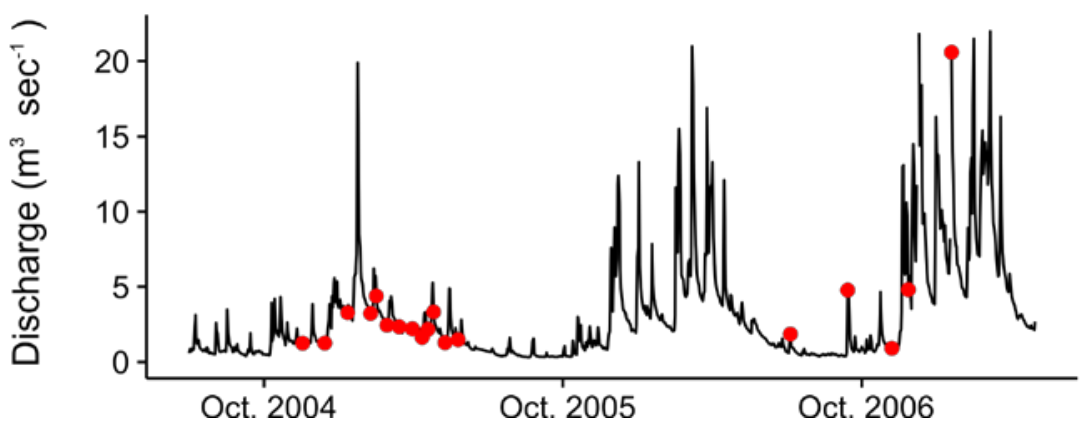

Figure 4. A) and B) Spatial representativeness of individual synoptic samplings in the Couesnon River as quantified by spatial stability: the rank correlation $\left(r_{s}\right)$ between the snapshot subcatchment concentrations and flow-weighted means. A value of 1 means that the sampling date perfectly predicts the relative flow-weighted mean concentration of the whole observation period. C) Daily discharge of the Couesnon River and timing of samplings. See Fig. S6 for the same information for the Rance watershed. 
A

Couesnon

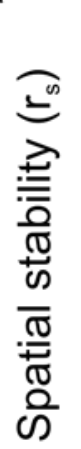

B

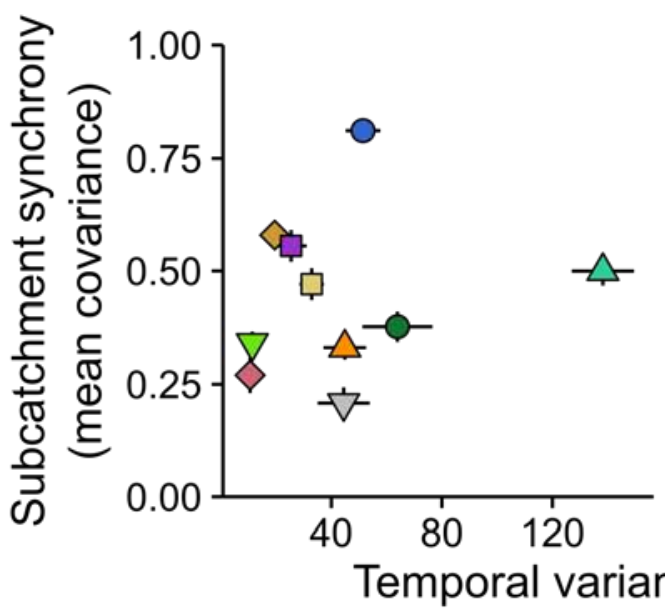

Rance

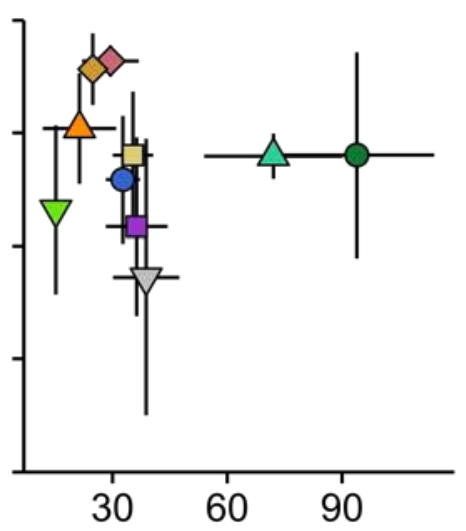

$\mathrm{CV} \%)$

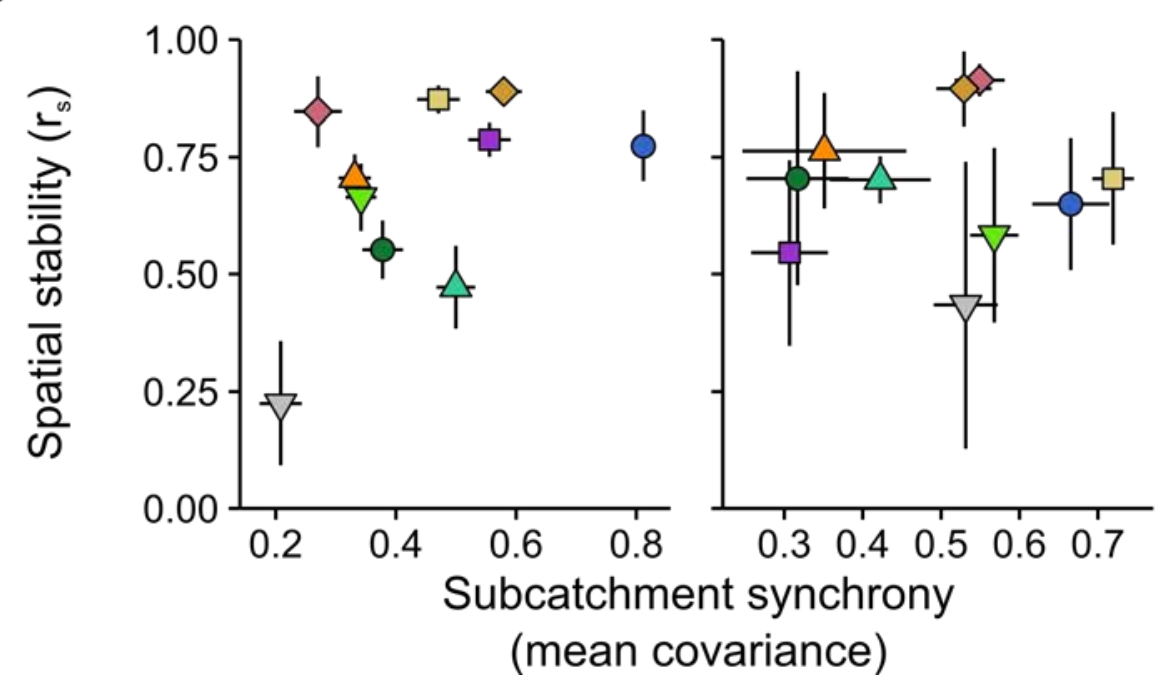

786 Figure 5. Relationships among mean spatial stability (rank correlation coefficient $\left(\mathrm{r}_{\mathrm{s}}\right)$ of individual sampling concentrations and the flow-weighted mean), coefficient of variation (CV) as a metric of temporal variability, and subcatchment synchrony (covariance) among subcatchments for all measured parameters. Error bars represent the 95\% confidence intervals of the mean. 


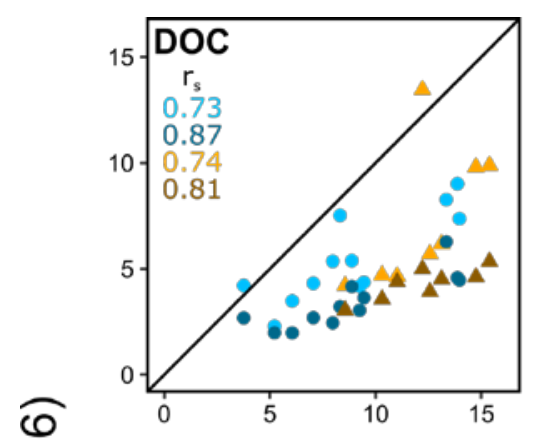

Couesnon

- 04-Nov-2015

- 22-Mar-2016

\section{Rance}

$\Delta$ 10-Nov-2015

A 24-Mar-2016
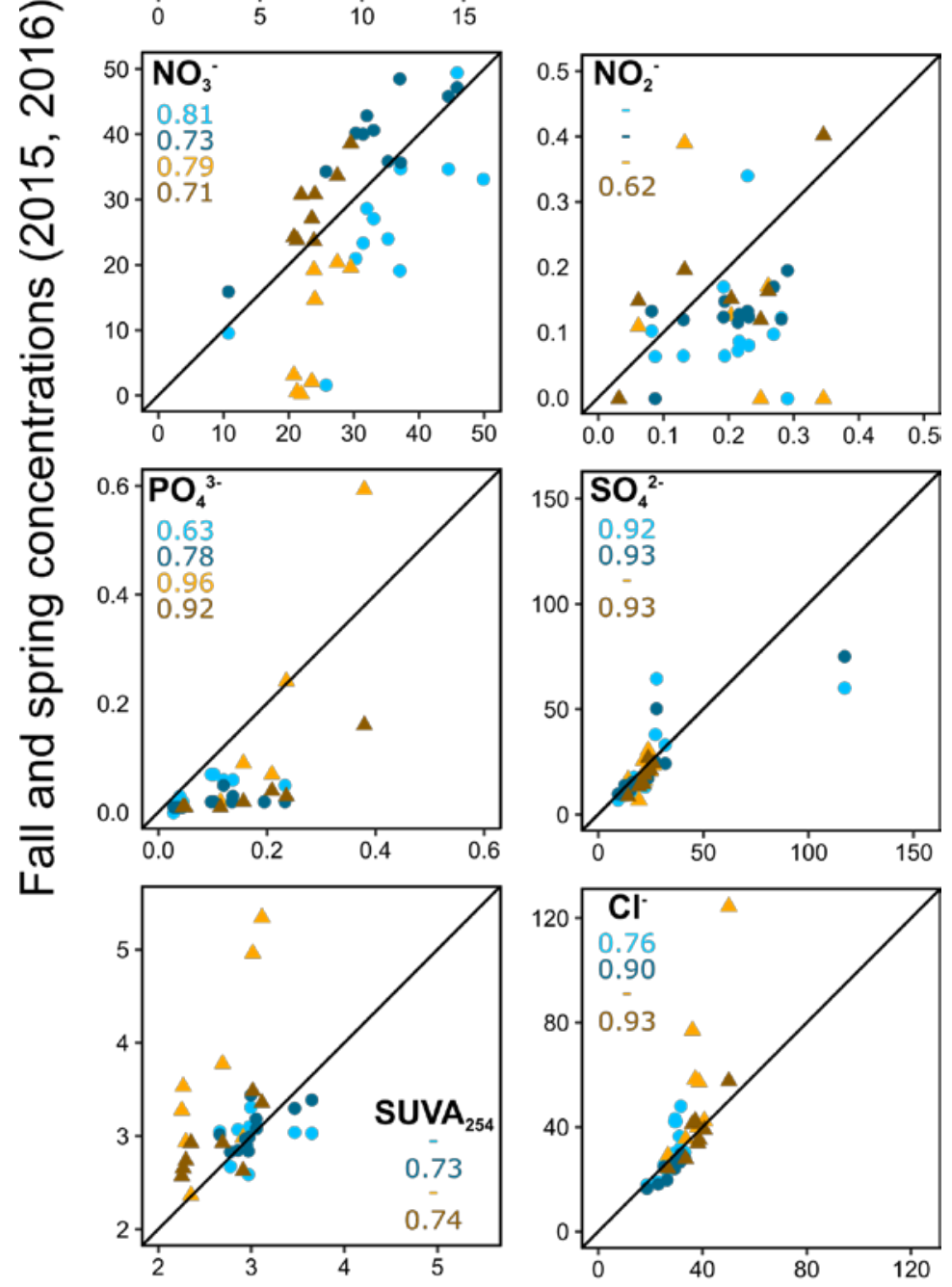

Flow-weighted mean concentrations (2004-2007)

Figure 6. Correlations between the flow-weighted mean concentration for 2004 to 2007 and individual samplings in 2015 and 2016 for the 21 resampled subcatchments. Significant rank correlations $(\alpha=0.05)$ are reported in each panel. Points falling above the 1:1 line were higher in 2015 and 2016 than from 2004 to 2007 and points below the line decreased in the time between. 